\title{
EDUCAREA TINERILOR: ÎNTRE SACRU ŞI PROFAN
}

\author{
Bondre-Motica Vlad-Ioan*
}

\begin{abstract}
Youth Education - between Sacred and Secular. Youth education, should not be an education opposed to education, but a set of theoretical ideas put into practice through faith. Education, youth and society together can be an analogy of the divine existence, because the common background of those is defined by value. This value should be reflected in relation with God and our kindreds. If the report sometimes designates a contradiction in terms and ideas, in youth education the relationship between sacred and secular must be seen as an addition. The idea is based on teaching of St. John Chrysostom which attests the need for a mentor and a father confessor because What is built in a place to be torn down in the other, and progress to be impossible
\end{abstract}

Keywords: Young people, contemporary society, secularization, sacred.

\section{Introducere}

Identificarea tinerilor cu opera de mântuire a Domnului Iisus Hristos este garantată de Sfânta Biserică, care, prin competenţa ei, păstrează nealterat adevărul revelat. Sub acest cadru, Biserica reprezintă locul de întâlnire a Cerului cu pământul, având ca linie de orizont năzuinţa membrilor ei, ca vlăstare pline de rod (In. 15, 5).

Dialogul dintre cele două cadre este prezentat sub forma unui catehism, şi face ca mesajul Evangheliei să fie trăit atât intensiv, cât şi extensiv. Atitudinea societăţii determină complementaritatea Bisericii de a exprima concis caracterul ei edificator şi educativ în vremi ce se văd a fi definite de spaţiul profan. Acesta este motivul pentru care educarea tinerilor reprezintă azi, balanţa între sacru şi secular.

Lucrarea acestora, a Bisericii şi a Societăţii, trebuie văzută în acest sens ca o pedagogie, lucru influenţat de modelul grecesc, în care viaţa trebuia să fie un centru cognitiv. Idealul sau asumarea valorilor avea numele de kalokagathia, ceea ce înseamnă armonia

* PhD Candidate, Faculty of Orthodox Theology at "1 December 1918 University”, Alba Iulia, Romania. 
dintre frumos şi bine. Condiţie sine qua non, adevărul, devine simbol al înţelepciunii, care este atestat de Înţeleptul Solomon prin cuvintele: Spune înţelepciunii: Tu eşti sora mea! (Prov. 7, 4), de unde reiese că tot ceea ce se schimbă este sensul în care societatea investeşte valorile ${ }^{1}$.

\section{Sensul şi valoarea educaţiei}

Plasarea cunoaşterii cognitive în vârful scării eclesiale de către Clement Alexandrinul şi accentul pus pe Evanghelie de către Origen, au produs o edificare a educării. Thomas Aquinas ajunge să afirme în acest sens că omul trebuie să descopere grija universală care determină natura fiecărui individ ${ }^{2}$. Orientarea trebuie să aibă în vedere secularismul, deoarece educaţia tinerilor îmbină valorile societăţii, dar şi izolarea de realitatea din jur. Din acest considerent, J. Andrew Kirk afirmă că educaţia religioasă nu are datoria doar de a transmite credinţa creştină, ci de a plasa valorile în viaţa creştină $\breve{a}^{3}$.

Pornind de la afirmaţia lui Johannes Verkuyl, conform căreia educaţia este cea mai veche formă de slujire din istoria modernă a misiologiei ${ }^{4}$, căutăm să reliefăm modul în care aceasta primește sigiliul Bisericii ca păstrătoare a adevărului de două milenii creştine. Educaţia creştină subliniază ideea centrală a cunoaşterii prin credinţă, motiv pentru care se autodepăşeşte de fiecare dată când întâmpină un

${ }^{1}$ F. Achim, A. Boja, O. Ignat, M. Maier, M.-Tereza Pirău, Prelegeri de didactică generală, Baia Mare, Edit. Universităţii de Nord, 2010, p. 42.

${ }^{2}$ H. M. Conn, Eternal word and changing worlds: Theology, Anthropology and Mission in trialogue, New Jersey, P \& R Publishing House, 1992, p. 274, apud W. Stanford Reid, Calvin and the founding of the Academy of Geneva, în Westminster Theological Journal, 18:1, November, 1955, p. 1-2.

${ }^{3}$ V. Leif Haanes, Theological education and mission, în Mission to the world: Communicating the Gospel in the 21-st Century. Essays in Honour of Knud Jorgensen, Tormod Engelsviken, Ernst Harbakk, Rolv Olsen, and Thor Strandenaes (editors), Oxford, Regnum in Cooperation with Egede Institute and Areopagos, 2008, p. 397-399.

${ }^{4}$ J. Verkuyl, Contemporary missiology. An introduction, Michingan, William B. Eerdmans Publishing Company, 1978, p. 220. 
obstacol creat de filosofia societăţii contemporane. Acest criteriu de regenerare a educaţiei religioase are fundamentul în ceea ce Însuşi Iisus Hristos a învăţat, astfel încât nici porţile iadului nu o pot birui (Mt. 16, 18).

Pedagogia cunoaşterii depline întrezăreşte noi căi de acces din direcţii diferite. Baza este reprezentată de cei şapte ani de acasă, despre care Danion Vasile vorbeşte, căutând să arate importanţa familiei în dezvoltarea tinerilor. Sub acest considerent, face precizarea că una din marile crize ale zilelor noastre este lipsa de modele vii. Tinerii simt nevoia să imite gesturi şi atitudini ${ }^{5}$. Răspunsul dat acestei crize atemporale trebuie căutat în paginile Sfintei Scripturi, acolo unde Iisus Hristos este prezentat ca un model al deplinătăţii cunoaşterii şi al înţelepciunii Eu sunt Calea, Adevărul şi Viaţa (In. 14, 6).

Văzut ca o ultimă realitate, nu doar ca purtător al adevărului, Iisus se identifică cu învăţătura Sa Eu sunt Lumina lumii; cel ce Îmi urmează Mie nu va umbla în întuneric, ci va avea lumina vieții (In 8, 12). Natura sa duală, lucrarea şi învăţătura $\mathrm{Sa}$, pun accentul pe puterea cuvântului ca transmitere a mesajului edificator ${ }^{6}$.

Obiectivele de referinţă ale Bisericii şi Societăţii, se identifică cu rolul celui care instruieşte spre dobândirea competenţelor necesare cunoaşterii. În acest sens, intervenţia reprezintă o abordare centrată pe persoană $\breve{a}^{7}$, deşi mesajul este de tip rezonator pentru toţi ceilalţi. Educarea tinerilor ca misiune a

${ }^{5}$ Vasile Danion, Cum să ne creştem copiii, Bucureşti, Edit. Sophia, 2002, p. 103-104. Căutarea unui model cere pricepere, atenţie, oglindire în personalitate. Acest aspect determină implicarea Bisericii în căutarea unei modalități de a-1 atrage pe tânăr spre Hristos. Chiar dacă programele catehetice se adresează tinerilor, fiind de real folos duhovnicesc, societatea prin natura ei politică, caută alte moduri de suscitare a minţii, pentru a obţine beneficii rapide pe termen scurt.

${ }^{6}$ W. D. Taylor, Global Missiology for the 21-st Century. The Iguassu Dialogue, Michigan, Baker Academic, 2000, p. 208-210.

${ }^{7}$ M. Maier, Cunoaştere, metacunoaştere şi acțiunea educativă, Cluj-Napoca, Edit. Risoprint, 2014, p. 18. 
Bisericii, nu reprezintă o îndoctrinare, ci un mod de prezentare a principiilor morale care duc la desăvârşire. Însuşirea învăţăturilor reprezintă fileul pus între dorinţă şi credinţă, căci astfel mintea le caută pe cele ale lui Dumnezeu, după sfatul Evanghelistului Matei: Căutaţi mai întâi împărăția lui Dumnezeu şi dreptatea Lui şi toate acestea se vor adăuga vouă (Mt. 6,33$)$.

Misiunea Bisericii într-un spaţiu prelungit al istoriei, arată capacitatea unor Sfinţi Părinţi de a înţelege rolul şi importanţa educaţiei, care devine punctul definitoriu al tânărului de azi. În acest sens, Fericitul Ieronim, în epistola sa Despre educaţia creştină, oferă un exemplu concret de educare, având la bază o trăsătură ascetică. Cuvintele lui pot reprezenta un îndreptar pentru tânăr, motiv pentru care cere: Să învețe să nu audă, nici să nu spună nimic altceva decât ceea ce are legătură cu frica de Dumnezeu. Cuvintele ruşinoase să nu le priceapă, să nu ştie cântece de lume, vorba să-i fie îmbibată din copilărie cu dulceaţa psalmilor ${ }^{8}$.

Adaptarea tinerilor la condiţiile Societăţii se face prin educaţie, ca răspuns al solicitărilor sistemelor politice, sociale, economice. Ieşirea din anonimat, succesul şi biruinţa devin armele cu care tânărul este chemat să lupte pentru a dobândi un loc fruntaş. Competiţia se remarcă prin încercarea de a fi mai bun, acest fapt contribuind la o creştere a interesului faţă de propria persoană. Din acest motiv, Biserica a făcut dintotdeauna precizarea că străduinţa trebuie îndreptată către aproapele, indiferent de gradul ei. Aceasta nu posedă un caracter antinomic, ci face apel la natura primordială a sufletului, de a oferi, ca mai apoi să primească.

\section{Educaţia noilor generații, între sacru şi secular}

Educarea tinerilor necesită o viziune de ansamblu asupra celor două lumi în jurul cărora tânărul îşi ţese viitorul. Dacă sacrul

\footnotetext{
${ }^{8}$ Fericitul Ieronim, Despre educaţia creştină, traducere din limba latină, introducere şi note de Remus Mihai Feraru, în „Altarul Banatului”, anul LVI, nr. 1-3, ianuarie-martie, 2006, p. 89-90.
} 
intervine în viaţa tânărului din momentul zămislirii şi Dumnezeu a făcut pe om şi a suflat în faţa lui suflare de viaţă (Fac. 2, 7), profanul caută să-şi adape setea prin experienţă. Această experienţă este văzută de ochii duhovniceşti ai Bisericii ca fuga către secularizare. Cele două drumuri, care, deşi par a fi paralele, au aceeaşi finalitate, educarea. Sfântul Apostol Pavel spune: Toate imi sunt îngăduite, dar nu toate îmi sunt de folos (I Cor. 6, 12), arătând prin aceasta că drumul ales poate duce spre pierzare, dacă scapă cuantificării. Educaţia tinerilor nu trebuie să fie o educaţie opusă educaţiei, ci un ansamblu de idei teoretice puse în practică prin credinţă. Raportul dintre educaţie, tineri şi societate, poate reprezenta o analogie a fiinţei divine, deoarece fondul comun al celor trei este reprezentat de valoare. Această valoare trebuie oglindită în raport cu Dumnezeu şi cu aproapele.

Relaţia dintre sacru şi laic, văzută prin prisma educaţiei tinerilor, reflectă o idee de a Părintelui Dorin Opriş care spune: Idealul acestei dimensiuni a educaţiei contemporane trebuie pus in relaţie directă cu concepţia despre om-fiinţă creată după chipul lui Dumnezeu spre ajungerea la asemănarea cu El, fapt sinonim cu a spune că idealul creştin nu este o idee despre ceea ce la un moment dat însumează perfecţiunea, ci o Persoană .

Deprinderea educării tânărului de azi, necesită mai mult ca oricând o formă graduală dar şi tact pastoral, fapt ce contravine dorinţei societăţii, care speră că va găsi un tânăr gata format pus pentru a milita în favoarea consumismului. Fenomenul maturizării poate fi înțeles alegoric, făcând trimitere la toiagul lui Moise care inmugurise, inflorise şi făcuse rod (Num. 17, 8), deoarece acest proces al edificării şi educării necesită o chemare a sinelui, care răspunde chemării lui Dumnezeu. Această învăţătură este văzută de Sfântul Ioan Gură de Aur atunci când el ne îndeamnă ca: în luna

\footnotetext{
${ }^{9}$ Dorin Opriş, Cercetarea experimentală în domeniul educaţiei religioase, între necesitate şi etică, în „Studii Teologice”, seria a III-a, anul VII, nr. 4, octombrie-decembrie, 2011, p. 225-226.
} 
aceasta de pildă să stăpânim bârfirea, batjocura, mânia. În luna cealaltă să ne învăţăm a nu fi răzbunători ... ${ }^{10}$.

Dacă educarea tânărului necesită aportul efectiv al acestuia în procesul propriu-zis, este de menţionat că acest lucru aduce cu sine perfecţionarea. Devierea tânărului de pe şina sacrului poate produce o extorsiune a puterii lăuntrice, care până atunci era alimentată de harul Duhului Sfânt. Integrarea într-un spaţiu nou, necunoscut, poate cauza suscitarea interesului pe întreg parcursul vieţii, motiv pentru care este de dorit ca cele două alternative, sacru şi laic, să găsească un numitor comun.

Conform lui Glen Heck şi Robert Meyers, acest numitor comun poate fi reprezentat de principiul libertăţii. Acest aspect afirmă că secularismul poate produce o educaţie modernă bazată pe progres. În cazul educaţiei sacre, accentul cade pe credinţă, iar acest lucru nu mai necesită nici o îndoială asupra autenticităţii ${ }^{11}$. Principiul este dus mai departe de Constantin Cucoş, care vede necesitatea pluralismului sau ecumenismului atunci când vine vorba de educaţie, dar pune accentul pe deschiderea Bisericii spre societate, pe care trebuie să o înţeleagă mai profund ${ }^{12}$.

Indicarea unei singure direcţii asupra educaţiei tinerilor, poate determina o repulsie faţă de fenomenul religios, deoarece azi societatea caută să facă o compilaţie între fundamente, fără a exclude o parte sau alta. Acestea trebuie privite ca un indicator spre sufletul tânărului, nu ca două sisteme diametral opuse care caută mereu să afişeze diferenţe. Atât educaţia religioasă, cât şi cea seculară sau laică, au datoria de a-şi îndrepta privirea spre ceea ce formează, nu spre ceea ce este deja format. În acest sens, se creionează ideea

${ }^{10}$ Florin Carebia, Principii şi metode de educaţie religioasă în opera Sfinţilor Trei Ierarhi, în „Altarul Banatului”, serie nouă, anul LXV, nr. 7-9, iulieseptembrie, 2015, p. 74.

11 G. E. Heck, and R. V. Meyers, Education in Secular and Christian Perspective, în Introduction to Biblical Christian Education, Werner C. Graendorf (ed.), Chicago, Moody Press, 1981, p. 305-319, passim.

12 Constantin Cucoş, Educaţia religioasă: Repere teoretice şi metodice, Iaşi, Edit. Polirom, 1999, p. 169-172, passim. 
conform căreia tânărul de azi va deveni stâlpul societăţii de mâine. Responsabilitatea aceasta trebuie primită cu deplină conştiinţă, dar şi cu multă încredere, de aceea cuvintele Sfântului Apostol Pavel Pot totul în Hristos care mă intăreşte (Filip. 4, 13), trebuie să sune fără oprire în sufletul şi în mintea tânărului de azi.

Dacă raportul desemnează uneori o contradicţie în termeni sau idei, în cadrul educaţiei tinerilor de azi, raportul dintre sacru şi laic trebuie văzut ca o completare. Noţiunea este fundamentată de învăţătura Sfântului Ioan Gură de Aur care atestă necesitatea unui îndrumător şi a unui duhovnic ca nu cumva ceea ce se zideşte într-o parte, să fie dărâmată în cealaltă, iar progresul să fie cu neputinţă $\breve{a}^{13}$.

Pentru a nu cădea în capcana deformării morale, trebuie împrumutat conceptul din mentalitatea chineză, acolo unde Yin primeşte puţin Yang, aşa cum Mihai Grigore vede în teologia lui Friedrich Graf faptul că în secularism nu este vorba de areligiozitate, ci de o religiozitate labilă şi mobilăa, lipsită de consistenţă, ce se adaptează mereu la lume şi la capriciile $e i^{14}$. Desigur, ideea de secularizare, din punctul de vedere al educaţiei tânărului de azi, poate avea o finalitate bolnavă, depărtându-l de la calea adevărului sau de la principiile fundamentale creştine. Dar grija Bisericii este văzută aici ca fiind năvodul care îl trage pe tânăr din capcanele pierzării, ducându-1 la limanul cel bun al dragostei în Iisus Hristos. Duhul libertăţii şi al reînnoirii în Hristos ${ }^{15}$ trebuie să definească educaţia religioasă a tânărului. Acest tânăr trebuie să transcende dincolo de

${ }^{13}$ Florin Carebia, Educaţia religios-morală şi factorii acesteia în concepţia Sfinţilor Trei Ierarhi (II), în Altarul Banatului, serie nouă, anul LXIII, nr. 4-6, aprilie-iunie, 2013, p. 74, apud. Tache Sterea, Actualitatea gândirii Sfinţilor Trei Ierarhi la sfârşit de mileniu, în „Studii Teologice”, seria a III-a, anul LI, nr. 1-2, ianuarie-februarie, 1999, p. 137-141.

${ }^{14}$ M. D. Grigore, Dii otiosi-postsecularism, metodă şi teologie la Friedrich Wilhelm Graf, în „Studii Teologice”, seria a III-a, anul V, nr. 1, ianuarie-martie, 2009, p. 242.

${ }^{15}$ Stelian Gomboş, Problema existenţei orei de religie-o abordare teologică şi apologetică, în „Altarul Banatului”, serie nouă, anul LVIII, nr. 1-3, ianuariemartie, 2008, p. 162. 
ispită şi să vadă în actul euharistic chemarea în Împărăţia Cerurilor. Dacă scopul vieţii este folosirea cu înţelepciune a darurilor lui Dumnezeu, atunci educaţia trebuie să fie pentru tânăr însuşi înţelepciunea pe care o foloseşte pentru a împlini misiunea la care a fost chemat.

Sinonim cu deschiderea socială a misiunii Bisericii, este şansa deschiderii spre lume şi spre contemporan ${ }^{16}$, ceea ce reprezintă pentru tânărul de azi un proces al dezvoltării personalităţii. Punctul de referinţă trebuie în schimb îndreptat spre autoobservaţie, acest proces însemnând mai mult decât o analiză, el fiind o etapă premergătoare Spovedaniei şi condiţie a concordanţei dintre faptă şi trăire ${ }^{17}$. Chiar dacă spaţiul în care tânărul îşi desfăşoară activitatea tinde să fie caracterizat de nonvaloare, implicarea lui directă în procesul educării sporeşte valenţele sacre din sufletul acestuia, deoarece perfecţiunea spre care ascede este un atribut al Persoanelor Divine. Înţelesul acesta trebuie văzut ca legătura creaţiei cu Creatorul.

\section{Educaţia tinerilor în contemporaneitate}

Frumuseţea educaţiei tinerilor este văzută de Părintele Dumitru Stăniloae ca fiind o lucrare din dragoste spre tot mai multă dragoste ... înfiinţând un raport de totală înţelegere şi negrăită comuniune $^{18}$. Modelul conservator al educaţiei, este văzut de tineri ca dorinţa de a fugi spre ceva ce le poate oferi control. Îngrădirea

\footnotetext{
16 Constantin Coman, Învăţământul teologic românesc şi provocările momentului istoric actual, în „Studii Teologice”, seria a III-a, anul III, nr. 4, octombrie-decembrie, 2007, p. 47.

${ }^{17}$ Monica Opriş, Metodologia cercetării pedagogice în domeniul educaţiei religioase. Specific, particularităţi, dificultăţi, în „Studii Teologice”, seria a IIIa, anul VIII, nr. 2, aprilie-iunie, 2012, p. 77.

${ }^{18}$ Florin Carebia, Educaţia religios-morală şi factorii acesteia în concepţia Sfinţilor Trei Ierarhi (I), în „Altarul Banatului”, serie nouă, anul LXIII, nr. 1-3, ianuarie-martie, 2013, p. 85, apud. Dumitru Stăniloae, Iisus Hristos sau restaurarea omului, Sibiu, 1943, p. 201.
} 
voinţei prin porunci, îi impulsionează în a alege ceva mult simplu, fără sens, unde ei deţin managementul situaţiei. În felul acesta, tinerii ajung să se înstrăineze de valorile perene, promovate de şcoală şi Biserică, adoptând o conduită excesivă, o ţinută promiscuă care tinde să devină un mod firesc de existenţă $\breve{~}^{19}$. Făcând o comparaţie între educaţia tinerilor şi munca unui sculptor care realizează o statuie, Preasfinţitul Părinte Paisie Lugojeanul vede dăltuirea fiinţei umane ca depinzând de personalitatea educatorului, cât şi de modul in care subiectul educat acceptă acest lucrü ${ }^{20}$.

Oferta epocii moderne ne conduce către noi idealuri, presărate de fenomenul globalizării dar şi de noi transformări în familia religiosului. Acest lucru începe cu schimbarea sensului educaţiei religioase, care devine azi o ideologie, lucru ce duce nemărginit la fenomenul secularizării şi globalizării, promovând un homo economicus ${ }^{21}$. Această raţiune este văzută de Părintele Vasile Citirigă ca refuzul cunoaşterii deplinătăţii lui Dumnezeu, motiv pentru care omul şi implicit tânărul a început să-şi dea sieşi şi să dea lucrurilor din lume înţelesuri şi rosturi străine de conţinutul lor ontologic $^{22}$.

${ }^{19}$ Florin Ardelean, Religia în şcoală în perspectiva integrării europene, în „Altarul Banatului”, anul LVI, nr. 7-9, iulie-septembrie, 2006, p. 139.

${ }^{20}$ Paisie Lugojeanu, Contribuţia orelor de religie la educaţia pentru toleranţă şi interculturalitate, în „Altarul Banatului”, serie nouă, anul LVII, nr. 1-3, ianuarie-martie, 2007 , p. 8.

${ }^{21}$ M. Morariu, O perspectivă ortodoxă asupra fenomenului secularizării, în Altarul Banatului, serie nouă, anul LXV, nr. 4-6, aprilie-iunie, 2015, p. 81, apud Teofil Tia, Homo Economicus şi criza sensului vieţii, în vol. Biserica în era globalizări, Alba-Iulia, Edit. Reîntregirea, 2003, p. 347; Cristinel Joja, Homo Economicus: Iisus Hristos, sensul creaţiei şi insuficienţei purului biologism, Timişoara, Edit. Marineasa, 2010. A se vedea şi Mihai Himcinschi, Homo technicus as contemporary missionary challenge, în „The Journal Symposium", vol. XIX: Alienation and Authenticity in Environments of the 21st Century: Technology, Person and Transcendence, New York, 2012, p. 4968, passim.

${ }^{22}$ Vasile Citirigă, Taina omului şi tragedia lui în epoca postmodernă, în „Ortodoxia”, anul LXII, nr. 3-4, martie-aprilie, 2006, p. 32. 
Evitarea efortului de către tânăr în dobândirea unei educaţii alese, contravine învăţăturii de credinţă, căci Sfântul Apostol Pavel îndeamnă să lucrăm cu frică şi cu cutremur la a noastră mântuire (Filip. 2, 12). Efortul este urmat de împlinire, iar acest lucru poate fi înţeles prin analogia dintre cel chemat şi cel ales, căci din momentul chemării acesta este deja ales. Pentru noua generaţie, Iisus Hristos trebuie să fie centrul vieţii, ca astfel drumul vieţii să fie desăvârşit.

Contemporaneitatea reprezintă câmpul de luptă a credinţei tânărului, care trebuie să aibă mijlocul încins cu adevărul şi să fie imbrăcat cu platoşa dreptăţii (Efes. 6, 14), ca nu cumva entuziasmul biruinţei să se transforme în eşecul sinelui cuprins de laicitate. Paravanul pus în calea dezvoltării duhovniceşti a tinerilor determină Biserica să ia o atitudine fermă în acest sens, iar direcţia spre care se îndreaptă lupta ei cea bună, este nestorianismul modern. Acesta nu face altceva decât să elimine elementul creștin, Dumnezeu rămânând doar un model de urmat şi nu de adorat. Urmarea lui Hristos ca Lider spiritual şi nu ca o convingere absolută, se poate înţelege prin sintagma Da pentru Iisus, Nu pentru Biserică. Acest aspect ridică ancora sentimentului de dor paradisiac din ungherele sufletului şi lasă de înţeles faptul că omul poate participa la viaţa spirituală, fără a se pocăi de păcatele săvârşite.

Responsabilitatea Bisericii faţă de membrii ei subliniază faptul că ea prezintă o atitudine riguroasă de a chema oamenii la adevăr şi credinţă, oferind cele necesare în lupta cu răul pentru ca omul lui Dumnezeu să fie desăvârşit şi cu totul destoinic pentru orice lucrare bună (II Tim. 3, 17). Transformarea omului, în acest sens, este opera lui Dumnezeu care ne angajează şi pe noi la transmiterea adevărului $^{23}$.

Restabilirea tânărului sau căutarea Sensului absolut şi autentic se face prin educaţie. Biserica alcătuieşte un proiect de lecţie duhovnicească de predare-asimilare a crezurilor, deoarece prin educaţie se poate ajunge la cauza primară a universului. Potrivit

${ }^{23}$ V. Samuel, and C. Sugden, Mission as Transformation: A theology of the whole gospel, Oxford, Regnum Books International, 1999, p. 275. 
îndemnului Sfântului Clement Romanul, trebuie să învăţăm pe tineri invăţătura fricii de Dumnezeu ... Copiii noştri să aibă parte de creşterea cea întru Hristos; să înveţe ce putere are smerenia înaintea lui Dumnezeu şi ce poate dragostea curată în faţa lui Dumnezeu; să inveţe că bună şi mare este frica de Dumnezeu şi că mântuieşte pe toţi cei care trăiesc cu cuvioşie în Dumnezeu, cu cuget curat ${ }^{24}$. Reuşita cere puterea exemplului, iar acest exemplu îşi are fundamentul în Sfânta Scriptură (Iov 6, 24; Is. 1, 17; In. 6, 45) şi în glasul epocii patristice. Tinerii au cea mai mare nevoie de educaţie, pentru a dezvolta în sine puterea cuvântului şi a faptei.

\section{Concluzii}

Se poate afirma că provocarea mediului secular şi sacru la un dialog ar putea forma o coaliţie pro-homo, dar să se treacă de la vorbe la fapte. Ceea ce le rămâne tinerilor este să se întoarcă la izvoarele credinţei, în sânul bisericii. Experienţa de viaţă de până atunci şi optica personală, îi pot determina să rămână în pridvorul bisericii sau să abandoneze. Cuvintele nu îi mai ajută foarte mult la redresarea pe un făgaş normal, pentru că sunt suprasaturaţi de persuasiune, acum vor dovada faptelor, vor viaţă, vor exemplul pe care să-l urmeze sau să i se dedice.

\section{Bibliografie}

1. *** Biblia sau Sfânta Scriptură, tipărită sub îndrumarea şi cu purtarea de grijă a Prea Fericitului Părinte Teoctist, Patriarhul Bisericii Ortodoxe Române, cu aprobarea Sfântului Sinod, Bucureşti, Edit. Institutului Biblic şi de Misiune al Bisericii Ortodoxe Române, Bucureşti, 2001.

2. Achim, F., Boja A., Ignat O., Maier M., Pirău M.-Tereza, Prelegeri de didactică generală, Baia Mare, Edit. Universităţii de Nord, 2010.

3. Ardelean, Florin, Religia în şcoală în perspectiva integrării europene, în Altarul Banatului, anul LVI, nr. 7-9, iulie-septembrie, 2006.

${ }^{24}$ I. Bursuc, Tinerii şi tinereţea în operele Sfinţilor Părinţi, în Solia, vol. LXXX, nr. 1-2, 2005, p. 19. 
4. Bursuc, I., Tinerii şi tinereţea în operele Sfinţilor Părinţi, în Solia, vol. LXXX, nr. 1-2, 2005.

5. Carebia, Florin, Educaţia religios-morală şi factorii acesteia în concepţia Sfinţilor Trei Ierarhi (I), în „Altarul Banatului”, serie nouă, anul LXIII, nr. 1-3, ianuarie-martie, 2013.

6. Carebia, Florin, Educaţia religios-morală şi factorii acesteia în concepţia Sfinţilor Trei Ierarhi (II), în „Altarul Banatului”, serie nouă, anul LXIII, nr. 4-6, aprilie-iunie, 2013.

7. Carebia, Florin, Principii şi metode de educaţie religioasă în opera Sfinţilor Trei Ierarhi, în „Altarul Banatului”, serie nouă, anul LXV, nr. 7-9, iulie-septembrie, 2015.

8. Coman, Constantin, Învătăământul teologic românesc şi provocările momentului istoric actual, în „Studii Teologice”, seria a III-a, anul III, nr. 4, octombrie-decembrie, 2007.

9. Conn, H. M., Eternal word and changing worlds: Theology, Anthropology and Mission in trialogue, New Jersey, P \& R Publishing, 1992.

10. Cucoş, Constantin, Educaţia religioasă: Repere teoretice şi metodice, Iaşi, Edit. Polirom, 1999. 